\title{
AGAPETA ZOEGANA (L.) (LEPIDOPTERA: COCHYLIDAE), A SUITABLE PROSPECT FOR BIOLOGICAL CONTROL OF SPOTTED AND DIFFUSE KNAPWEED, CENTAUREA MACULOSA MONNET DE LA MARCK AND CENTAUREA DIFFUSA MONNET DE LA MARCK (COMPOSITAE) IN NORTH AMERICA
}

\author{
H. MÜlleR ${ }^{1}$, D. Schroeder, and A. GassmanN \\ C.A.B. International Institute of Biological Control, CH-2800 Delémont, Switzerland
}

\begin{abstract}
Can. Ent. 120: 109-124 (1988)

The taxonomy, distribution, life history, and host plant relationships of the cochylid moth Agapeta zoegana (L.), an oligophagous, facultatively multivoltine root feeder, are discussed. The results of oviposition and larval feeding tests with 56 plant species in five families are presented and show that $A$. zoegana is restricted to a few closely related species of Centaurea. In Europe the moth is widely distributed and abundant in the majority of the root-feeding guilds of Centaurea maculosa Monnet de la Marck studied, with densities of 23.6 larvae per 100 roots in eastern Austria/northwestern Hungary and less than 8 larvae per 100 roots in central Hungary and the Alsace. The acceptance of target North American species (the tetraploid form of $C$. maculosa and the diploid Centaurea diffusa Monnet de la Marck), the damage caused, and the active searching ability rate $A$. zoegana as a potentially effective natural enemy of spotted and diffuse knapweed in North America. Agapeta zoegana will be especially promising as it predominantly attacks the rosette, which is, according to a recently developed population model for diffuse knapweed in Canada, the most sensitive stage determining equilibrium knapweed density. Agapeta zoegana is compatible with Pelochrista medullana Staudinger (Lepidoptera: Cochylidae), another knapweed root feeder recently introduced into North America, and will complement the seed-feeding species already established. The moth was approved for release in Canada and the USA and has been established in British Columbia since 1984 on $C$. diffusa.
\end{abstract}

\section{Résumé}

Cette contribution porte sur la taxonomie, la distribution, le cycle vital et les relations avec les plantes-hôtes du papillon cochylide Agapeta zoegana (L.), une espèce radicicole oligophage facultativement multivoltine. Les résultats de tests de ponte et d'alimentation des larves avec 56 espèces de plantes appartenant à cinq familles sont rapportés, et montrent que $A$. zoegana est spécifique de quelques espèces apparentées de Centaurea. En Europe le papillon est largement distribué et abondant dans la majorité des communautés radicicoles associées à Centaurea maculosa Monnet de la Marck qui ont été étudiées, avec des densités de 23,6 larves par 100 racines dans l'est de l'Autriche-nord de la Hongrie, et moins de 8 larves par 100 racines en Hongrie centrale et en Alsace. L'acceptation d'espèces nord-américaines visées, la forme tétraploïde de C. maculosa et l'espèce diploïde $C$. diffusa Monnet de la Marck, les dommages infligés, de même que la capacité de recherche élevée de A. zoegana en font un auxiliaire naturel de lutte contre la centaurée maculée et la centaurée diffuse en Amérique du Nord. Agapeta zoegana sera d'autant plus efficace qu'il attaque la rosette, soit le stade critique pour la détermination de la densité d'équilibre de la centaurée d'après un modèle démographique de la centaurée diffuse récemment mis au point au Canada. Agapeta zoegana est compatible avec Pelochrista medullana Staudinger (Lepidoptera: Cochylidae), une autre espèce radicicole associée à la centaurée qui a été récemment introduite en Amérique du Nord, et s'ajoutera donc aux espèces déjà établies. Le relâchement du papillon a été approuvé au Canada et aux USA, et il est établi en ColombieBritannique depuis 1984 sur $C$. diffusa.

\section{Introduction}

Spotted knapweed, Centaurea maculosa Monnet de la Marck, a short-lived perennial, and diffuse knapweed, Centaurea diffusa Monnet de la Marck, typically a biennial, both

\footnotetext{
'Present address: Zoologisches Institut der Universität Basel CH-4051 Basel, Switzerland.
} 
of European origin, were accidently introduced into Canada and the northern United States with seed grain (apparently alfalfa) from southeastern Europe. Centaurea maculosa was first discovered in Victoria, B.C., in 1893 (Groh 1943), and C. diffusa was first recorded in Washington State in 1907 (Howell 1959). Several factors, including suitable ecological conditions, extensive overgrazing of the natural vegetation, the allelopathic properties of the Centaurea spp. (Fletcher and Renney 1963), and prolific seed production, enhanced their establishment and spread. Today, spotted knapweed is most abundant in Montana, where approximately 800000 ha are infested (Maddox 1979). In British Columbia the weed occurs on some 4000 ha and is most abundant in the forest steppe region (Harris and Cranston 1979). In 1972, C. diffusa infested 25952 ha of dry grassland in British Columbia and small areas in Alberta (Watson and Renney 1974) and Harris and Cranston (1979) expect that it will continue to spread; some 7.5 million ha of open uncultivated sites are susceptible for infestation.

Both species tend to dominate the natural vegetation where they become established. Losses of available forage on natural pastures may attain 88\% (Harris and Cranston 1979). Chemical control with picloram is possible but not economic for most of the infested area, and cultivation is often not possible because of the topography and other adverse factors. Harris and Cranston (1979) concluded that an increased investment in biological control should be made as it would be expected to give a superior return to alternative methods of control.

Between 1970 and 1972, three seed-feeding species (two tephritids (Urophora affinis Frauenfeld and $U$. quadrifasciata Meigen) and a gelechiid (Metzneria paucipunctella Zeller)) were released and established in British Columbia (Harris and Myers 1984). A root-feeding buprestid beetle (Sphenoptera jugoslavica Obenberger) was first released in 1976 and became established at White Lake, B.C. (Harris and Myers 1984). Despite the establishment of these natural enemies, which resulted in a drastic decline of seed production in both knapweed species, no change in plant density has occurred (Harris and Myers 1984). The investigation of additional biocontrol agents was proposed in 1977 by the Canadian Department of Agriculture. A second faunistic survey was initiated by the Commonwealth Institute of Biological Control, Delémont (CIBC) in 1979 to investigate the species of insects associated with the roots of the two knapweed species in their native range in Europe.

The objective of this study was to investigate the life history, ecology, and host specificity of the root-mining moth Agapeta zoegana (L.). The impact of the moth on host and target plants was also studied to determine its potential for the biological control of the two knapweed species in North America.

\section{Materials and Methods}

Field Studies. The general survey carried out between 1979 and 1983 comprised 4 sites in France, 4 sites in Germany, 15 sites in Austria, 7 sites in Hungary, 6 sites in Czechoslovakia, and 15 sites in Rumania for $C$. maculosa (110 samples), 7 sites in Rumania for C. diffusa (41 samples), and 11 sites in Switzerland and 2 sites in Italy for $C$. vallesiaca (de Candolle) Jordan (41 samples) (Fig. 1). Most localities were sampled several times and in different seasons. Each sample contained 50-100 randomly sampled plants. These were dissected in the laboratory to assess the root-feeding entomofauna. This also provided information on interspecific associations of the root-feeding insects. To determine voltinism, additional root samples were collected at 2-week intervals from late May to late August at Dürnstein in Lower Austria (1981, 1982), at Julia Major in central Hungary (1982, 1983), and at Hanu Conachi in eastern Rumania (1982). During the same periods, pheromone trials were carried out at these localities (Tóth et al. 1985).

The abundance and distribution of $A$. zoegana larvae on $C$. maculosa were studied at Dürnstein (dry grassland on a steep, south-facing slope on silicate rock), at Sopron, 


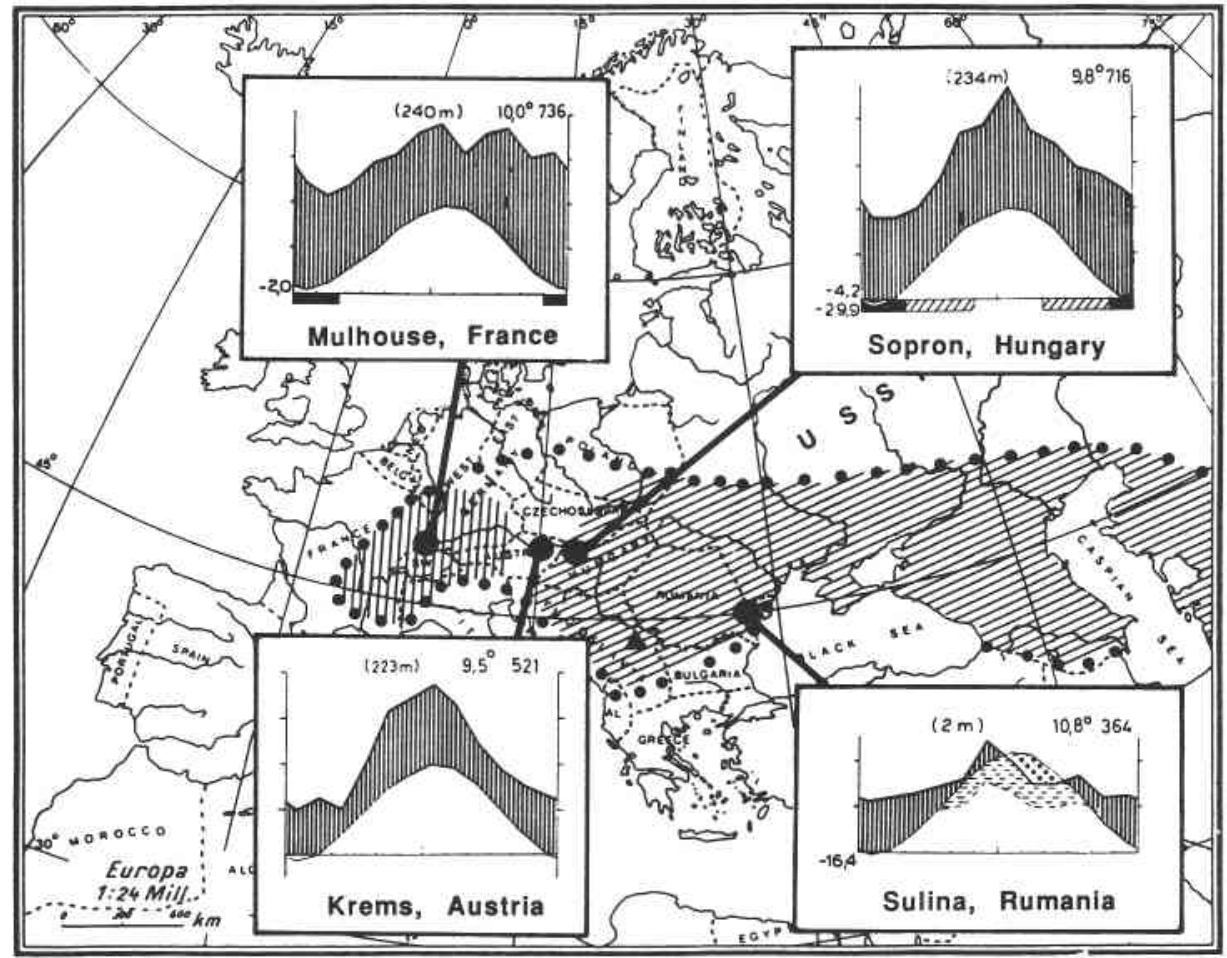

III C.. maculosa Lam. ssp. maculosa (= CE.stoebe ssp. maculosa (Lam.) Hayek)

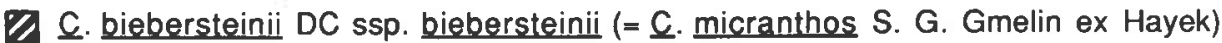
$(=$ C. maculosa Lam, $2 n=36 ; \approx$ target weed in North America)

Q c. rhenana Boreau (incl. all ssp.) ( $=$ C . maculosa Lam, $2 n=18$; studied host plant in Europe)

- Main collection and study area for A. zoegana, with corresponding climatic diagrams (legend see Fig. 2D)

FIG. 1. Main collection and study areas of Agapeta zoegana, corresponding climatic diagrams (Walter and Lieth 1967), and geographic distribution of three taxa of the Centaurea maculosa group of species.

western Hungary (dry wasteland on limestone), and at Sollenau, eastern Austria (a chalkgravel pit). A transect method (2 by $50 \mathrm{~m}$ long) was applied (Whaba 1970) to determine knapweed density. At each locality, 200 randomly selected plants were collected and dissected to assess incidence and level of infestation and dispersion of $A$. zoegana larvae on host plants. Large samples of up to 1000 infested roots were collected at the end of May or in early June at Dürnstein, Sollenau, Sopron, and Hanu Conachi. All material used for laboratory studies at Delémont originated from these areas.

Laboratory Rearings and Life History Studies. Roots containing final-instar larvae and pupae of $A$. zoegana were collected from the various sites and brought to Delémont. The material was kept in emergence cages between layers of moistened cellulose sheets in a $16 \mathrm{~L}: 8 \mathrm{D}$ cycle, at $23-25^{\circ} \mathrm{C}$ and $80-90 \% \mathrm{RH}$. Adults emerging from the cages were used to study mating and oviposition, and to obtain larvae for host specificity screening. Most 
of the investigations were carried out on potted plants in a temperate greenhouse $\left(18-30^{\circ} \mathrm{C}\right.$, $30-80 \% \mathrm{RH}$, and natural photophase), supplemented by field cage studies. Mating, longevity, oviposition, and fecundity were studied in oviposition cages ( 36 by 36 by $62 \mathrm{~cm}$ high) in the greenhouse. Each cage contained four bolting $C$. maculosa plants of North American origin in pots ( $12 \mathrm{~cm}$ in diameter). These plants were exposed to two males and two females of A. zoegana, which were kept in the same cage until they died. For food, the moths were offered a honey-sugar solution and knapweed flowers. Larval development and feeding niches of the different instars were followed by dissecting infested roots at different time intervals after hatching.

Mortality Factors. Parasitism was studied from larvae collected in the field in June and July. Parasitoids were obtained from individually reared larvae and also from mass rearings from roots collected at sites where A. zoegana was the only known root feeder. Observations on predators were made in the field.

Association with other Root Feeders. The occurrence of frequently associated root-feeding insect species was studied at 12 localities between 1979 and 1983, to determine the association of $A$. zoegana with other root feeders.

Larval survival of $A$. zoegana in association with the moths Stenodes straminea Haworth and Pelochrista medullana Staudinger was investigated on potted plants. Two, five, or a varying density from one to five first-instar larvae were transferred to 5 or 10 plants per series. Each species was tested alone (single-species transfer) or in association with one or two other root feeders (multi-species transfer).

Host Specificity Screening Tests. During field surveys between 1979 and 1981, A. zoegana was found exclusively on $C$. maculosa and $C$. arenaria Bieberstein und Willdenov; however, there are several other species of Cynareae recorded as host plants in the literature. To collect information on the potential host range of the moth, oviposition and larval feeding tests were carried out. Test plants were selected in cooperation with Dr. P. Harris and the Working Group on the Biological Control of Weeds, Beltsville, MD. Systematically closely related crop plants of economic importance are safflower, Carthamus tinctorius L., and globe artichoke, Cynara scolymus L. Oviposition tests were conducted at Delémont during July and August in a greenhouse at natural photoperiod and a temperature range of $15-30^{\circ} \mathrm{C}$. Four potted plants in cages ( 36 by 36 by $62 \mathrm{~cm}$ high) were exposed to two or three couples of $A$. zoegana for the entire life of the moths (ca. 10 days). Oviposition tests were conducted first in the presence and second in the absence of spotted or diffuse knapweed. Only cages containing fertilized eggs were included in the analysis. Between two and eight replicates were made. The plants were arranged in random combinations and the position of the cages was changed periodically. Further oviposition tests were carried out in field cages ( 100 by 200 by $100 \mathrm{~cm}$ high) with the test species transplanted in the field.

Eggs obtained from oviposition tests were incubated in glass tubes and newly emerged larvae were used for larval transfer tests. Two or three vigorous and actively moving larvae per plant were transferred with a fine brush. Infested plants were kept in the garden at Delémont until November, at which time the plants were dissected to check plant acceptance and larval development.

Effect on the Host Plant. The ability of larvae to move from the first attacked plant to a neighboring plant was also assessed. Three $C$. maculosa rosettes, grown from Chase, B.C., seeds, were planted $10 \mathrm{~cm}$ apart in each of 15 large pots $(20 \mathrm{~cm}$ diameter $)$. In 10 pots, 15 first-instar larvae were put on one of the three plants and each rosette was isolated by a plastic cylinder to exclude above ground migration of the larvae. Five pots were used as controls for plant mortality other than root mining. In addition, experiments in glassfaced root containers ( 5 by 50 by $100 \mathrm{~cm}$ long) (Müller 1984, 1987) and with potted 
rosettes were conducted to study the effect of root mining on spotted knapweed rosettes of different origin (genome), different age, and grown in different soil types. Plants were infested by transferring three first-instar larvae to the bases of the rosette leaves.

\section{Results}

Taxonomy and Host Plant Records of Agapeta. The genus Agapeta Hübner belongs to the family Cochylidae and consists of four Palearctic species and one subspecies, A. zoegana ssp. brunneocycla Razowski. Synonyms for A. zoegana (L.) are Tortrix ferrugana Haworth, Aethes zoegana Billberg, and Euxanthis ab. ferrugana Kennel (Razowski 1970). The biology of $A$. zoegana ssp. brunneocycla Razowski is unknown and its distribution is limited to southeastern Yugoslavia.

Agapeta zoegana is known to occur throughout Europe with the exception of Greece. The northern distribution limit follows latitude $60^{\circ} \mathrm{N}$, the eastern border apparently reaches the Urals, the southern and western borders are not defined (Razowski 1970). The morphological description for the moth and the final-instar larva of $A$. zoegana are given by Razowski (1970) and Swatchek (1958), respectively. Host plants are only known for two Agapeta species, A. hamana L. and A. zoegana. According to literature records, A. hamana feeds on the leaves of Ononis repens L., and possibly also on Trifolium pratense L. and Cirsium arvense (L.) Scopoli. Agapeta zoegana has been recorded to feed on the roots of Scabiosa columbaria L., Centaurea jacea L., C. maculosa, C. nigra L., C. paniculata L., Jurinea linearifolia de Candolle, and probably C. scabiosa L. (Hannemann 1964; Razowski 1970; Schütze 1931; Bradley et al. 1973).

Knapweed Taxonomy. Three species of the $C$. maculosa groups were found within the area surveyed during this study (eastern France, southern Germany, Switzerland, northern Italy, Austria, Czechoslovakia, Hungary, and Rumania). According to Flora Europea (Dostál 1976), these were $C$. maculosa Monnet de la Marck ssp. maculosa $(=C$. stoebe ssp. maculosa (Monnet de la Marck) Hayek), C. rhenana Boreau (incl. all ssp.), and C. biebersteinii de Candolle ssp. biebersteinii $(=C$. micranthos Gmelin ex Hayek) (Fig. 1).

Investigations of $A$. zoegana carried out in Austria, France, and Hungary were made on the diploid host plant classified as $C$. rhenana. However, the problem species in North America keys out to $C$. biebersteinii ssp. biebersteinii $(2 n=36)$. This species occurs mainly in southeastern Europe and was not included in the European CIBC surveys (see also Schroeder 1985). The morphology, biology, and distribution of $C$. biebersteinii ssp. biebersteinii in Canada is described by Watson and Renney (1974). In this report, the name C. maculosa (sensu Lat.) is used for both the European and the American spotted knapweeds. Centaurea diffusa is taxonomically well defined, and North American and European plants seem to belong to the same species (Watson and Renney 1974; Moore and Frankton 1974).

Geographic Distribution of Agapeta zoegana in Europe and Potential Range in North America. In our surveys between 1979 and 1981, A. zoegana was found on C. maculosa in eastern Austria (Lower Austria and Burgenland) and western and central Hungary (Sopron and Budapest area). The moth also occurred on C. arenaria in eastern Europe (Hanu Conachi and Danube Delta) and small populations were found on C. maculosa in the upper Rhine Valley (Alsace and Istein). Possibly, "local species" (sensu Fox and Morrow 1981) of A. zoegana have evolved within the general European distribution area.

Field observations suggested that the presence of $A$. zoegana in knapweed stands was determined primarily by site conditions, and to a lesser extent by host plant species. Within the survey area $A$. zoegana occurred predominantly in semi-natural, undisturbed sites (e.g. dry grassland, steppic biotopes, and south-facing slopes) and ruderal habitats (e.g. gravel quarries), but was rare or absent on sites with strongly fluctuating populations of spotted knapweed. Grazing by sheep has apparently no adverse effect on its occurrence. 


\section{CANADA}

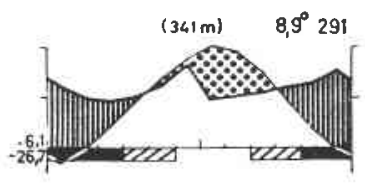

A: Penticton, B. C.

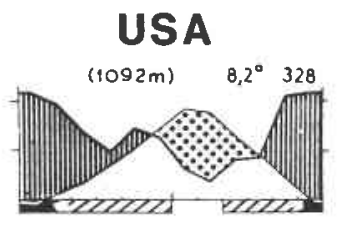

C: Bend, OR

Legend

a- station

b. altitude

c - mean annual temperature $\left({ }^{\circ} \mathrm{C}\right)$

d- mean annual sum-total of precipitation $(\mathrm{mm})$

e - mean daily minimum of the coldest month

f - absolute temperature minimum

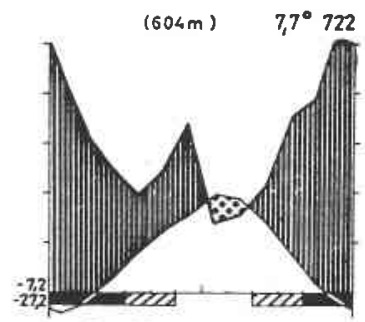

B: Nelson, B.C.

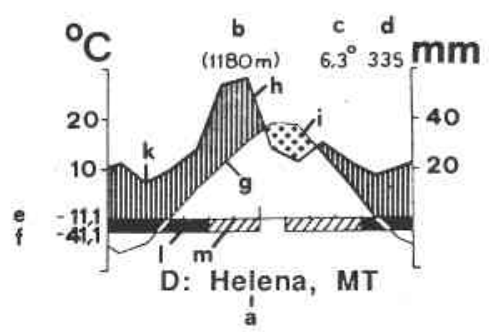

g- monthly means of temperature

$\mathrm{h}$ - monthly means of precipitation

$i$ - period of drought

$k$ - period of humidity

I - months with mean daily minimum below $0^{\circ} \mathrm{C}$ (black)

$\mathrm{m}$ - months with absolute minimum below $0^{\circ} \mathrm{C}$ (hatched)

Fig. 2. Climatic diagrams of North American Centaurea maculosa and $C$. diffusa infestation areas (Walter and Lieth 1964).

In Europe A. zoegana occurred in areas with a moderately humid temperate climate and in areas with an arid sub-continental climate (Fig. 1). This corresponds with summer conditions of spotted and diffuse knapweed-infested areas in Canada, although these regions have colder winters and a shorter summer season than infested sites in Europe (Fig. 2).

Agapeta zoegana may, therefore, need some period of time to acclimatize to the colder climate in southern Canada and the northern USA before it is able to colonize the entire area presently infested by spotted knapweed. Collections from the more arid sub-continental Rumanian areas may be better suited for release in the southern part of the spotted knapweed distribution in the USA and diffuse knapweed sites in Canada, whereas the Austrian and Hungarian populations from a moderately continental climate should be released in spotted knapweed sites in the interior of British Columbia and Montana.

Analyses of root samples and data from pheromone traps indicate that A. zoegana had two generations per year in eastern Austria and western and central Hungary (June to early August and end of August to September). Up to three annual generations may occurin southeastern Rumania (moths are found from May to September; F. König, pers. communication), two generations were found in 1982 at Hanu Conachi (June to mid-July and July to late August), but only one generation occurs in western Europe (moths from July to August; Alsace, Delémont). In North America, A. zoegana will probably have one annual generation in most areas, but possibly two generations in areas with climatic conditions shown in Figure 2A. 
Table 1. Infestation and dispersion of Agapeta zoegana larvae on Centaurea maculosa ( $n=200$ randomly collected plants)

\begin{tabular}{|c|c|c|c|c|c|c|}
\hline & \multicolumn{2}{|c|}{ Dürnstein, Austria } & \multicolumn{2}{|c|}{ Sollenau, Austria } & \multicolumn{2}{|c|}{ Sopron, Hungary } \\
\hline & 1981 & 1982 & 1981 & 1982 & 1981 & 1982 \\
\hline Host plants $/ \mathrm{m}^{2}$ & 0.5 & 0.2 & 3.0 & 2.1 & 0.5 & 0.1 \\
\hline Infestation (\%) & 16 & 18 & 20 & 15 & 36 & 15 \\
\hline $\begin{array}{l}\text { Dispersion index } \\
s^{2} / \bar{x}\end{array}$ & 1.0 & 1.6 & 2.1 & 1.3 & 2.4 & 2.2 \\
\hline $\begin{array}{l}\text { No. of larvae/ } \\
\text { attacked root } \\
\bar{x}( \pm \text { SD })\end{array}$ & $\begin{array}{c}1.21 \\
(0.41)\end{array}$ & $\begin{array}{c}1.41 \\
(0.75)\end{array}$ & $\begin{array}{c}1.43 \\
(1.20)\end{array}$ & $\begin{array}{c}1.25 \\
(0.58)\end{array}$ & $\begin{array}{c}2.03 \\
(1.53)\end{array}$ & $\begin{array}{c}1.70 \\
(1.13)\end{array}$ \\
\hline
\end{tabular}

The mean larval densities and the distribution of multiple attack on C. maculosa at Dürnstein, Sollenau, and Sopron are given in Table 1. Spotted knapweed reached densities of only up to 0.5 plants $/ \mathrm{m}^{2}$ in the more natural, undisturbed habitats with relatively high plant cover (Dürnstein, Sopron), but knapweed densities up to 3 plants $/ \mathrm{m}^{2}$ were found in ruderal areas at Sopron. The variance:mean ratio, an index for dispersion that is unity for a Poisson (random) distribution (Southwood 1978), was calculated for the six samples and indicates random and slightly clumped distributions for $A$. zoegana larvae on individual roots; clumping depends on the availability of larger roots which can support several larvae (Table 1). Altogether $25 \%$ of the attacked C. maculosa had two or more larvae in their roots.

Emergence, Mating, and Longevity. In the laboratory, emergence from overwintered, field-collected material took place over an 8-week period, from mid-June to mid-August. Collections from warmer sites produced adults earlier than those from cooler sites (Table 2). Emergence after hibernation of $A$. zoegana may be largely determined by temperature, as demonstrated by transferring potted plants infested by hibernating final-instar larvae from the Institute's garden into the insectary in February 1980 . The larvae kept at $20^{\circ} \mathrm{C}$ and natural photophase emerged in March and April compared with July for those under field conditions.

Comparisons of emergence between males and females were made for populations from Sopron and Hanu Conachi in 1980. The difference between mean emergence dates of the two sexes, based on 3-day intervals, was not statistically different $(p=0.05)$ for both populations ( $n=138, t=0.375$ and $n=27, t=0.767$, respectively).

The females mated within $24 \mathrm{~h}$ of emergence. Successful mating occurred in a temperature range between 18 and $30^{\circ} \mathrm{C}$ (outdoors, insectary) and did not require the presence of the host plant.

Under the test conditions described, males ( $n=75, \bar{x} \pm \mathrm{SD}=11.8 \pm 1.96$ days) lived significantly longer $(t=6.08, p<0.01)$ than females $(n=66, \bar{x} \pm \mathrm{SD}=9.9 \pm 1.77$ days $)$.

Table 2. Emergence of Agapeta zoegana in 1981

\begin{tabular}{lcccc}
\hline & \multicolumn{2}{c}{ Centaurea maculosa } & & Centaurea arenaria \\
\cline { 2 - 3 } & Dürnstein, Austria & Sopron, Hungary & & Hanu Conachi, Rum. \\
\hline Mean annual temp. $\left({ }^{\circ} \mathrm{C}\right)^{*}$ & 9.5 & 9.8 & 10.8 \\
No. of moths & 20 & 51 & 91 \\
Emergence period & 1 July -14 Aug. & 26 June -9 Aug. & & 16 June - 30 July \\
Mean emergence date $\dagger$ & 16 July a & 14 July a & & 6 July b \\
\hline
\end{tabular}

*Walter and Lieth (1967).

†Analysis based on 3-day intervals; ANOVA: $F=19.3, p<0.001$. Means with the same letter are not significantly different $(p=0.05$; Scheffé $F$-test) 
Table 3. Longevity, fecundity, and fertility of eggs of Agapeta zoegana emerged at different periods

\begin{tabular}{|c|c|c|c|c|c|c|c|}
\hline \multirow{2}{*}{$\begin{array}{l}\text { Emergence } \\
\text { period }\end{array}$} & \multicolumn{4}{|c|}{ Mean longevity (days) } & \multirow{2}{*}{$\begin{array}{c}\text { Temp. }{ }^{*} \\
\left({ }^{\circ} \mathrm{C}\right)\end{array}$} & \multirow{2}{*}{$\begin{array}{c}\text { Mean no. of } \\
\text { eggs/fem. }\end{array}$} & \multirow{2}{*}{$\begin{array}{c}\text { Incidence of } \\
\text { fertility }+\end{array}$} \\
\hline & $n$ & Male & $n$ & Female & & & \\
\hline \multicolumn{8}{|l|}{1980} \\
\hline 26 June - 3 July & 10 & 14.4 & 8 & 9.3 & $17.0 \mathrm{a} \uparrow$ & $20.5 \mathrm{a}^{\dagger}$ & $59.8 \% \mathrm{~b} \dagger$ \\
\hline 14 July - 18 July & 12 & 11.2 & 8 & 10.3 & $26.3 b$ & $55.0 \mathrm{c}$ & $44.6 \% \mathrm{~b}$ \\
\hline 24 July - 13 Aug. & 10 & 10.9 & 9 & 9.1 & 22.06 & $35.0 \mathrm{~b}$ & $25.6 \% \mathrm{a}$ \\
\hline \multicolumn{8}{|l|}{1981} \\
\hline 29 June - 5 July & 12 & 10.1 & 9 & 12.6 & $24.4 a b^{\dagger}$ & $62.4 \mathrm{a}^{\dagger}$ & $32.7 \%$ a $†$ \\
\hline 8 July - 11 July & 12 & 11.1 & 9 & 12.6 & $23.5 \mathrm{a}$ & $66.4 \mathrm{a}$ & $45.8 \% \mathrm{ab}$ \\
\hline 14 July - 1 Aug. & 14 & 13.2 & 10 & 8.1 & $25.4 b$ & $94.4 b$ & $51.1 \% \mathrm{~b}$ \\
\hline
\end{tabular}

*Average of mean daily temperature during life of moths (emergence period plus mean longevity of the females).

†Values followed by the same letter are not significantly different at $p=0.05$ (ANOVA, Scheffé $F$-test)

$\ddagger$ Data were angularly transformed (arc sin $\sqrt{p}$ ) prior to statistical analysis.

Oviposition and Fecundity. Oviposition began 1 day after mating. The eggs were laid singly, or in groups of up to three eggs, on the surface of stems and leaves, predominantly in crevices. Approximately $30 \%$ of the eggs were laid on the frame of the oviposition cages. However, in a field cage containing different phenological stages of $C$. maculosa, the majority of the eggs were laid on the lower leaves, mostly on rosettes.

The eggs were oval in shape and somewhat flattened, length $=0.73 \pm 0.04 \mathrm{~mm}$, width $=0.44 \pm 0.04 \mathrm{~mm}(\bar{x} \pm S D)$. The eggs were whitish when freshly laid and turned reddish with 3-4 days. The chorion was reticularly scupltured and quite robust.

Experiments on fecundity and fertility of eggs were conducted in the insectary during the same time period in 1980 and 1981 (Table 3). Females that emerged in the middle (1980) or the end (1981) of the emergence periods and that lived at higher temperatures laid more eggs than females from the beginning (1980) or the middle (1981) of the emergence period and that lived under cooler temperatures. However, in 1980 successful mating was more frequent in the beginning (lower temperature) than at the end of the emergence period, but was reversed in 1981, i.e. more frequent at the end and under higher temperatures. Hence, although temperature may influence total fecundity of $A$. zoegana, other factors were responsible for the fertility of the eggs.

Hatching and Larval Development. In the laboratory, the larvae emerged 7-10 days after oviposition when kept in a $16 \mathrm{~L}: 8 \mathrm{D}$ cycle, at $90 \% \mathrm{RH}$ and $23-24^{\circ} \mathrm{C}$. The larvae emerged through a lid-like portion of the chorion and moved immediately to the root crown area where they started mining. There are six larval instars. Roots dissected 10 days after the transfer of newly emerged larvae contained $6 \%$ first-instar and $94 \%$ second-instar larvae. Only fourth-instar larvae, which had already mined up to $10 \mathrm{~cm}$ into the cortical tissue of the taproot, were observed 40-45 days after transfer, and only sixth-instar larvae were found beyond the 70th day. Young larvae mined the tissue just below the exodermis, but older larvae mined progressively downwards in open, irregular, sometimes spiral mines which were covered with a whitish web spun by the larvae. Heap capsule widths of the instars were as follows: first, $0.19-0.20 \mathrm{~mm}$; second, $0.26-0.27 \mathrm{~mm}$; third, $0.36-0.44$ $\mathrm{mm}$; fourth, $0.56-0.68 \mathrm{~mm}$; fifth, $0.71-0.86 \mathrm{~mm}$; sixth, $0.95-1.50 \mathrm{~mm}(n=2-32)$. The increase in head capsule widths from one larval instar to the next agreed with predicted values from Dyar's Law, indicating a geometrical growth.

Mortality Factors. In laboratory rearings, natural mortality of embryos was low. Mortality in the first instar was important, especially on small plants with multiple attack, as larval transfer tests on potted plants demonstrated. Predaceous staphylinids (Ontholestes haraldi (Eppelsheim) and Xantholinus linearis Heer) and elaterid larvae were found in empty mines of $A$. zoegana in $C$. maculosa roots from Austria and Hungary. 
Only parasitoids emerging from final-instar larvae or pupae were assessed. Parasitism of A. zoegana was relatively high, ranging from 11 to $60 \%$ (Müller 1984). It varied from locality to locality and from year to year. Sixteen species of hymenopterous parasites (see Müller 1984) emerged from roots of $C$. maculosa and C. arenaria infested by $A$. zoegana. Nine parasite species were reared from $A$. zoegana, including six braconid species, each of which occurred at less than six sites. The ectoparasites Bracon larvicida Wesmael, $B$. praetermissus Marshall, and B. indubius Szépligeti accounted for less than 5\% parasitism, but the solitary endoparasites Chelonus annulipes Wesmael and Chelonus sculpturatus (Szépligeti) parasitized up to $30 \%$ of the larvae. Chelonus intermedius Szépligeti was only found at Sopron, Hungary, where it parasitized $43 \%$ of A. zoegana larvae in 1980 . The ichneumonids Glypta sculpturata Gravenhorst parasitized $10 \%$ of the larvae at two sites, and four specimens of $G$. bivolveolata Gravenhorst were reared from east Rumanian material. A polyembryonic Copidosoma species (Encyrtidae) parasitized up to $35 \%$ of the larvae at three localities.

The only available host record from North America concerns Chelonus annulipes, a common parasite of Ostrinia nubilalis Hübner, introduced and established in the USA (Muesebeck et al. 1951; Herting and Simmonds 1975).

The abundance of A. zoegana in most of the root-feeding guilds on C. maculosa in central Europe despite relatively high rates of parasitism indicates, therefore, its importance as a natural enemy of spotted knapweed populations.

Association with other Root Feeders. Agapeta zoegana was the second most common species in eastern Austria/northwestern Hungary on $C$. maculosa following the pooled Apion spp. (Müller 1984; unpublished data). An average of 23.6 larvae per 100 knapweed roots was found in eastern Austria/northwestern Hungary, but less than 8 larvae per 100 roots were found in central Hungary and the Alsace, France (Müller 1984).

Eight species were frequently associated with $A$. zoegana. These were three Lepidoptera ( $S$. straminea (Cochylidae), $P$. medullana (Tortricidae), and Pterolonche inspersa Staudinger (Pterolonchidae)), two weevils (Cleonus piger Scopoli and Cyphocleonus achates Faber), two Diptera (Cheilosia sp. (Syrphidae) and Pegohylemyia centaureae Hennig (Anthomyiidae)), and the buprestid beetle $S$. jugoslavica. In addition, four Apion species (Coleoptera: Curculionidae) occurred in the collections, but they are recorded as a single taxon in this study.

The interspecific association (Southwood 1978), i.e. the joint occurrence of species on the same root, was random, except for $C$. achates, which was positively associated with A. zoegana. Both species hibernate as larvae within the taproot. Preliminary observations that $C$. achates selected larger rosettes for oviposition (C.S.A. Stinson, pers. communication), and the fact that smaller rosettes infested by A. zoegana often die during winter, is a possible explanation for this positive association found in late spring before the emergence of these two species.

The survival of $A$. zoegana in different densities, as well as in association with $S$. straminae and $P$. medullana, was also tested on potted rosettes in the greenhouse. When feeding alone, about half of the $A$. zoegana and $S$. straminea larvae survived (Table $4 a$ ). Cannibalistic behavior accounted for the reduced survival of $P$. medullana (Gassmann $e t$ al. 1982). The higher herbivore load in the case of multi-species transfer was responsible for the increased mortality of the larvae, but no asymmetrical competition occurred (Table $4 b$ ).

The reduced survival of $A$. zoegana in association with $P$. medullana compared with the association with $S$. straminea can be explained by the different feeding site of $S$. straminea (at the bases of the rosette leaves and the root collar) (Müller 1983); A. zoegana and $P$. medullana share the same feeding site in the root cortex. Thus, field and laboratory experiments indicate that $A$. zoegana will be compatible with $P$. medullana, an additional 
Table 4. Survival of Agapeta zoegana (A), Stenodes straminea (S), and Pelochrista medullana (P) in various intra- and inter-specific associations in 1983/1984

(a) Single-species transfer

\begin{tabular}{|c|c|c|c|}
\hline & Agapeta & Stenodes & Pelochrista \\
\hline \multicolumn{4}{|l|}{ Infestation (July/Aug.) } \\
\hline No. of pots & 5 & 5 & 5 \\
\hline No. of larvae/pot & $1,2,3,4,5$ & $1,2,3,4,5$ & $1,2,3,4,5$ \\
\hline $\begin{array}{l}\text { No. of larvae alive } \\
\text { in April (total survival) }\end{array}$ & $7=46.7 \%$ & $8=53.7 \%$ & $2=13.3 \%$ \\
\hline
\end{tabular}

(b) Multi-species transfer

\begin{tabular}{|c|c|c|c|c|c|c|}
\hline \multirow[b]{3}{*}{ No. of pots } & \multicolumn{6}{|c|}{ Association of larvae transferred } \\
\hline & \multicolumn{2}{|c|}{$A+S$} & \multicolumn{2}{|c|}{$\mathbf{A}+\mathbf{P}$} & \multicolumn{2}{|c|}{$A+S+P$} \\
\hline & 5 & 5 & 5 & 5 & 10 & 10 \\
\hline No. of larvae/ & & & & & & \\
\hline \multicolumn{7}{|c|}{$\begin{array}{l}\text { No. of larvae alive in } \\
\text { April in association of }\end{array}$} \\
\hline $\begin{array}{l}\text { April in associat } \\
\text { A }\end{array}$ & 2 & 0 & 1 & 1 & 0 & 0 \\
\hline $\mathrm{S}$ & 3 & 2 & - & - & 4 & 3 \\
\hline $\mathrm{P}$ & - & - & 1 & 0 & 0 & 0 \\
\hline$A+S$ & $3+2$ & $7+7$ & - & - & $3+3$ & $4+3$ \\
\hline $\mathrm{A}+\mathrm{P}$ & - & - & $3+2$ & $1+1$ & 0 & 0 \\
\hline$A+S+P$ & - & - & - & - & $1+1+1$ & $1+1+1$ \\
\hline \multicolumn{7}{|l|}{ Survival $(n)$ of } \\
\hline A (Total (\%) & 5 & 7 & 4 & 3 & 4 & $5=23.3 \%$ \\
\hline$S$ of species & 5 & 9 & - & - & 8 & $7=30.9 \%$ \\
\hline P survival) & - & - & 3 & 1 & 1 & $1=6.3 \%$ \\
\hline $\begin{array}{l}\text { Total larval } \\
\text { survival (\%) }\end{array}$ & 33.3 & 80.0 & 23.3 & 20.0 & 21.6 & 8.7 \\
\hline
\end{tabular}

root feeder recently imported for the biological control of $C$. diffusa, as well as with $S$. jugoslavica, a root feeder already established in British Columbia on diffuse knapweed (Harris and Myers 1984).

Host Specificity Screening Tests. The results of the oviposition tests are summarized in Tables 5 and 6 . Altogether 51 plant species, comprising 45 Compositae and six representatives of four other families, were screened. Although the orientation of ovipositing females in the cages may be disturbed, 17 of the tested plant species were consistently avoided, including $S$. columbaria, which is recorded as a host plant in the literature. However, eggs were laid on many plant species unsuitable for larval development and $30 \%$ of the eggs were deposited on the wooden frames of the test cages. A few eggs were deposited on $C$. tinctorius and $C$. scolymus in the presence of $C$. maculosa (Table 5), but these crop plants received no eggs in the absence of $C$. maculosa (Table 6).

To demonstrate that $C$. tinctorius and $C$. scolymus are not acceptable for oviposition in the field, even in close proximity to $C$. maculosa, five males and three females of A. zoegana were released into a field cage containing five naturally growing plants, in different phenological stages, of each of the following species: C. maculosa, C. montana L., C. nigrescens Willdenow, $C$. tinctorius, and $C$. scolymus. A total of 176 eggs was recovered, of which $84 \%$ were found on C. maculosa, $15 \%$ on C. nigrescens, and $1 \%$ on $C$. montana. No eggs were found on $C$. tinctorius or $C$. scolymus, and no larvae had moved to the roots of these species from the adjacent $C$. maculosa plants, on which up to 25 larvae were found on a single root. Only one living larva was found on C. montana 
and two larvae on $C$. nigrescens. Two additional tests in field cages were conducted. One rosette and one flowering plant of each $C$. tinctorius, $C$. scolymus (two rosettes), and four knapweed species including C. maculosa were exposed to three and five pairs of $A$. zoegana. No eggs or larvae were found on the two critical crop plants and C. maculosa was strongly preferred. These tests also showed that rosettes of $C$. maculosa were preferred over flowering plants for oviposition; $81 \%$ of the eggs laid on C. maculosa were found on rosettes.

A total of 970 first-instar larvae were transferred onto 56 plant species, including different phenologicn stages of the host and target species. Successful establishment and normal larval develcipment were restricted to a few closely related species of Centaurea, i.e. $C$. maculosa, $C$. arenaria, and to a lesser extent $C$. diffusa, $C$. vallesiaca, and $C$. nigrescens. A single larvae survived until November on Arctium lappa L. and C. orientalis L., and two larvae were found on Plectocephalus americana (Nuttall) in very small mines. These larvae were all retarded in their development. Not a single larva became established on $C$. jacea L., and only a small percentage of the transferred larvae survived on $C$. nigrescens which was readily accepted for oviposition in the field tests. Three larvae of $A$. zoegana nibbled on the roots of $C$. tinctorius and developed to second and third instar before they died. Two additional plants per species were tested by transferring a total of 15 newly hatched larve, three at a time in a 5-day interval on each plant. All these larvae died in the first instar without nibbling.

Experimental investigations of the potential host range of $A$. zoegana therefore indicate that the species is restricted to a few closely related species of Centaurea. The tests clearly demonstrated a strong preference for the European host plants (including $C$. vallesiaca, formerly treated as a subspecies of $C$. maculosa (Hess et al. 1977)) and the two North American target species, and that the two closely related crop plants safflower and globe artichoke are not at risk. Moreover, $C$. tinctorius is harvested in late summer, 1 month after the expected oviposition of $A$. zoegana.

Effect on the Host Plant. The larvae of A. zoegana damaged their host plant by mining the roots. The damage caused by first and second instars, which mine the root collar area just below the exodermis, is negligible. The feeding of late instars, however, caused considerable damage, especially on small roots or when several larvae were present on large roots. The larvae produced irregular mines in the cortex and the endodermis of roots over $7 \mathrm{~mm}$ in diameter, whereas in smaller roots, or near the tip of the taproot, mining occurred predominantly in the central part of the root, i.e. in the vascular system. Smaller roots, however, were completely destroyed, with just a small part of the root collar left.

To determine the effect of larval feeding, 15 potted young rosettes each of spotted and diffuse knapweed were infested with three first-instar larvae of $A$. zoegana. On examination 70-80 days later, one plant had died for unknown reasons, the roots of 26 wilting plants (11 spotted and 15 diffuse knapweed) had been completely destroyed, and no trace of larval feeding was found on three healthy plants. All larvae found had reached the final instar.

Small plants were destroyed by the feeding of a single larva. As most of the eggs were laid on young rosettes of the predominantly biennial European C. maculosa, attacked plants often were killed before producing flowers. At a high plant density, in which the majority of the rosettes remain small, a single larva may destroy several rosettes before completing its development.

The experiment to test below ground migration of $A$. zoegana from one plant to another showed that larvae were able to find a new host plant within $10 \mathrm{~cm}$, if the root of their primary host plant had been consumed. All the infested and half of the neighboring plants died, compared with only 2 of the 15 plants in the control pots. Although $81 \%$ of the larvae transferred died, 27 of the 28 survivors were found on the originally uninfested 


\begin{tabular}{|c|c|c|c|c|c|c|c|}
\hline \multirow[b]{3}{*}{ Test plant } & \multirow[b]{3}{*}{$\begin{array}{l}\text { Plant } \\
\text { type* }\end{array}$} & \multicolumn{2}{|c|}{ Oviposition test } & \multicolumn{4}{|c|}{ Larval development test } \\
\hline & & & Mean no. of eggs & No, of & & & $\%$ alive as \\
\hline & & $\begin{array}{l}\text { No. of } \\
\text { repl. }\end{array}$ & $\begin{array}{c}\text { laid/fem./test } \\
\text { on the plant }\end{array}$ & $\begin{array}{l}\text { larvae } \\
\text { transf. }\end{array}$ & $\begin{array}{l}1 \text { st } \\
\text { instar }\end{array}$ & $\begin{array}{l}\text { 4th } \\
\text { instar }\end{array}$ & $\begin{array}{l}\text { 6th inst. } \\
\text { in Nov. }\end{array}$ \\
\hline
\end{tabular}

FAM. PAPILIONACEAE

Lathyrus odoratus $\mathrm{L}$.

Medicago sativa $\mathrm{L}$.

Trifolium pratense $\mathrm{L}$. in Nov.

\section{FAM. CARYOPHYLLACEAE}

Silene cucubalus Wib.

$\begin{array}{lll}\text { A } & 4 & 0 \\ \text { P } & 3 & 0 \\ \text { B-P } & - & -\end{array}$

FAM. DIPSACACEAE

Dipsacus sp.

Scabiosa columbaria L.

FAM. CYSTACEAE

Helianthemum vulgare Gaertn.

\section{FAM. COMPOSITAE}

Tribe: Astereae

Aster novi-belgii L,

Asrer amellus L.

Erigeron annuus (L.) Pers.

Solidago canadensis L.

Grindelia nana (Nutt.)

Tribe: Heliantheae

Helianthus tuberosus L.

Helianthus decapetatus $\mathrm{L}$.

Helianthus annuus L.

Rudbeckia hirta L.

15
15
15

0
0
0

$\begin{array}{lll}P & 4 & 0\end{array}$

15

0

Tribe: Helenieae

Tagetes erectus L.

Tribe: Anthemideae

Achillea millefolium $\mathrm{L}$.

Achillea filipendulina Lam

Artemisia vulgaris L.

Artemisia tridentata Nutt.

Artemisia cana Pursh.

Chrysanthemum leucanthemum $\mathrm{L}$.

Santolina chamaecyparissus L.

Anthemis tinctoris $\mathrm{L}$.

Matricaria matricaroides (Less.) Porter

Tribe: Senecioneae

Senecio jacobaea L.

Tribe: Calenduleae

Calendula officinalis $\mathrm{L}$. 
Tribe: Cichorieae

Cichorium intybus L.

Lactuca sativa $\mathrm{L}$

Sonchus arvensis $\mathrm{L}$.

Taraxacum officinale Web.

Tribe: Cynareae

Arctium lappa L.

Cnicus benedictus $\mathrm{L}$

Cynara scolymus L.

Cirsium arvense (L.) Scop.

Cirsium undulatum (Nutt.) Spreng.

Echinops sphaerocephalus L.

Onopordum acanthium L.

Silybum marianum (L.) Gaertn.

Carthamus tinctorius $\mathrm{L}$.

Carthamus lanatus $\mathrm{L}$.

Rhaponticum scariosum Lam.

Plectocephalus americanus (Nutt.)

Genus: Centaurea

Subgenus: Lopholema

Centaurea orientalis L.

Subgenus: Acrolophus

Centaurea cineraria (gymnocarpa) L.

Centaurea maculosa Lam. (Europe)

Rosettes

Flowering plants

Centaurea maculosa (North Am.)

Rosettes

Centaurea vallesiaca (DC) Jordan

Rosettes

$\mathrm{P}$
$\mathrm{P}$
$\mathrm{P}$

$5 \quad 7.6$

$6-15$

Centaurea diffusa Lam. (North. Am.)

Rosettes

Flowering plants

Centaurea arenaria L.

Subgenus: Jacea

Centaurea jacea $\mathrm{L}$.

Centaurea nigrescens Willd.

P 6

2.0

$\begin{array}{ll}\mathrm{P} & 4\end{array}$

Subgenus: Psephellus

Centaurea dealbata Willd.

Subgenus: Cyanus

P 3

*A: annual; B: biennial; P: perennial.

fOne specimen died in the pupal stage. 
Table 6. Oviposition and larval development test in the absence of Centaurea maculosa and Centaurea diffusa

\begin{tabular}{lcc}
\hline $\begin{array}{l}\text { Test plant } \\
\text { (3 repl./plant species) }\end{array}$ & $\begin{array}{c}\text { Mean no. of hatched eggs/ } \\
\text { female/test on the plant }\end{array}$ & $\begin{array}{c}\text { No. of larvae } \\
\text { alive after 50 days }\end{array}$ \\
\hline $\begin{array}{l}\text { Carthamus tinctorius } \text { L. } \\
\text { Cynara scolymus L. }\end{array}$ & 0 & 0 \\
Helianthus tuberosus L. & 0 & 0 \\
Centaurea montana L. & 18 & 0 \\
Centaurea orientalis L. & 3 & $1\left(\mathrm{~L}_{1}\right)$ \\
Centaurea jacea L. & 5 & 0 \\
Centaurea nigrescens Willd. & 6 & $2\left(\mathrm{~L}_{4}\right)$ \\
& 43 & $1\left(\mathrm{~L}_{4}\right)$ \\
\hline
\end{tabular}

neighboring plants. This further demonstrated the potential effectiveness of A. zoegana as a knapweed control agent.

Experiments in root containers revealed distinct differences in the biology between the European diploid host plant C. maculosa and the North American tetraploid target species (Müller 1984, 1987). It is expected that the smaller biomass of the tetraploid species (root length, dry weight, and number of flower heads and seeds per year) and its polycarpic, perennial life cycle compared with the monocarpic, biennial diploid plants (Müller 1984, 1987) may influence the effect of A. zoegana.

Table 7 summarizes experiments with potted plants to compare the impact of $A$. zoegana on the mortality of spotted knapweed rosettes of different origin, different age, and grown in different soil types. No statistical differences in plant mortality could be found due to the limited number of replicates. However, the results suggest that the impact of larval feeding did not differ among plants of different age (A versus C, Table 7), that the North American target plants were more susceptible to attack than the European host plants (A versus B), and that plants grown in poor soil were more susceptible than plants grown in nutrient-rich soil (C versus D).

The potential control value of A. zoegana was earlier assessed by Müller et al. (1982) on the system developed by Harris (1973) and revised by Goeden (1983). This indicated a good prospect as a biological control agent compared with other insects imported for weed control (Goeden 1983). However, this system only scores attributes of species, which in general increase the probability of a relevant damage to the plant (Wapshere 1985) without considering its potential for a regulative impact on the target weed population. A recently developed population model for diffuse knapweed in Canada (J. Myers, pers. communication) suggests that population dynamics is buffered from effects of reduced seed numbers, but that rosette survival is essential in determining knapweed equilibrium density. Agapeta zoegana can severely damage North American spotted knapweed rosettes. Feeding on roots directly reduces the storage capacity of the root as well as the uptake of

Table 7. Impact of Agapeta zoegana on mortality of potted Centaurea maculosa rosettes of different origin (genome) and age, and grown in different soil types (three first-instar larvae per pot were transferred in July)

\begin{tabular}{|c|c|c|c|c|}
\hline & \multicolumn{4}{|c|}{ Treatment } \\
\hline & A & B & C & $\mathrm{D}$ \\
\hline \multirow{2}{*}{$\begin{array}{l}\text { Origin of plant } \\
\text { (genome) }\end{array}$} & Europe & Canada & Europe & Europe \\
\hline & $2 n=18$ & $2 n=36$ & $2 n=18$ & $2 n=18$ \\
\hline Plants infested $(n)$ & 20 & 20 & 10 & 10 \\
\hline \multicolumn{5}{|l|}{ Age of rosettes } \\
\hline (months) & 8 & 8 & 4 & 4 \\
\hline Soil type (cf. text) & Humus & Humus & Humus & Sand \\
\hline \multicolumn{5}{|l|}{ Dead plants after } \\
\hline 5 months $(n)$ & 8 & 13 & 4 & 8 \\
\hline
\end{tabular}


water and nutrients (Crawley 1983). Mining of roots also enhances the susceptibility to infection by pathogens. Our study showed that several larvae developed on the same plant, and that the larvae searched for additional plants if they depleted their food supply before termination of larval development. This suggests that $A$. zoegana should be a highly effective biological control agent.

Several moths of $A$. zoegana caught in pheromone traps in Summerland, B.C., in August 1985, from field releases in 1983 (unpublished data), confirmed a first successful establishment. Large populations of moths reared in field cages at Kamloops, B.C., were released in 1986 in areas infested by spotted knapweed near Kamloops. They were caught in pheromone traps in 1987, proving their successful overwintering in the field. However, the insect's progress in North America needs to be carefully monitored to test our prediction that the additional stress imposed by $A$. zoegana will decrease knapweed density by increasing rosette mortality, and hence will complement the effects of the seed-feeding species already established.

\section{Acknowledgment}

For insect identification we acknowledge the help of J.-F. Aubert, A.D. Austin, Z. Boucek, M. Capec, J.F. Chainey, B.H. Cogan, M.L. Cox, L. Dieckmann, R.H.L. Disney, M.G. Fitton, I.D. Gould, M.S.K. Ghauri, J. Quinlan, K.M. Harris, R.P. Lane, R. Madge, A.C. Pont, W. Sauter, B.R. Subba Rao, J.M. White, R.M. Wilson, N.P. Wyatt, and W. Topp. We acknowledge R.D. Goeden, P. Harris, M. Rowell-Rahier, H.F. Rowell, C.S.A. Stinson, and J.K. Waage, as well as J.N. McNeil and two anonymous reviewers for their helpful suggestions on earlier drafts of this manuscript.

\section{References}

Bradley, J.D., W.G. Tremevan, and A. Smith. 1973. British tortricoid moths. Cochylidae and Tortricidae: Tortricinae. The Ray Soc. Mon. 147. 251 pp.

Crawley, M. 1983. Herbivory - The Dynamics of Animal Plant Interactions. Blackwell Publications, Oxford. $437 \mathrm{pp}$.

Dostál, J. 1976. Centaurea L. pp. 254-301 in Flora Europaea. Vol. 4. Cambridge Univ. Press. 505 pp.

Fletcher, R.A., and A.J. Renney. 1963. A growth inhibitor found in Centaurea spp. Can. J. Plant Sci. 43: $475-481$.

Fox, L.R., and P.A. Morrow. 1981. Specialization: species property or local phenomenon? Science 211: 887893.

Gassmann, A., D. Schroeder, and H. Müller. 1982. Investigations on Pelochrista medullana (Stgr) (Lep. Tortricidae), a possible biocontrol agent of diffuse and spotted knapweed, Centaurea diffusa Lam. and $C$. maculosa Lam. (Compositae) in North America. Final Report, CIBC, Delémont.

Goeden, R.D. 1983. Critique and revision of Harris' scoring system for selection of insects agents in biological control of weeds. Prot. Ecol. 5: 287-301.

Groh, H. 1943. Canadian Weed Survey. 2nd Annu. Rep. Can. Dept. Agric. 74 pp.

Hannemann, H.J. 1964. Kleinschmetterlinge oder Microlepidoptera. II. Die Wickler s. 1. (Cochylidae unf Carposinidae). Die Zünslerartigen (Pyra- loidea) in Die Tierwelt Deutschlands, Dahl et al. (Eds.), Vol. 50. 401 pp.

Harris, P. 1973. The selection of effective agents for the biological control of weeds. Can. Ent. 105: 14951503.

Harris, P., and R. Cranston. 1979. An economic evaluation of control methods for diffuse and spotted knapwood in Western Canada. Can. J. Plant Sci. 59: 375-382.

Harris, P., and J.H. Myers. 1984. Centaurea diffusa Lam. and C. maculosa Lam. s. lat., diffuse and spotted knapweed (Compositae) in biological control programmes against insects and weeds in Canada 19691980. Agric. Bur.: 127-137.

Herting, B., and F.J. Simmonds. 1975. A Catalogue of Parasites and Predators of Terrestrial Arthropods. Section A, VI, 1, Commonwealth Agricultural Bureau, Slough. p. 176.

Hess, H.E., E. Landolt, and R. Hirzel. 1977. Centaurea Lam. pp 436-457 in Flora der Schweiz und angrenzende Gebiete, Band 3. Birkhäuser Verlag, Basel und Stuttgart.

Howell, J.T. 1959. Distribution data on weedy thistles in western North America. Leafl. West. Bot. 9: 17-29.

Maddox, D.M. 1979. The knapweeds: their economics and biological control in the Western States. U.S.A. Ranglands 1: 139-143. 
Moore, R.J., and C. Frankton. 1974. The Thistles of Canada. Research Branch Canada Dept. Agric. Monograph 10. p. 81.

Muesebeck, C.F.W., K.V. Krombein, and H.K. Townes. 1951. Hymenoptera of America North of Mexico. USDA Agric. Monograph 2, Washington, DC. 1420 pp.

Müller, H. 1983. Untersuchungen zur Eignung von Stenodes straminea Haw. (Lep.: Cochylidae) für die biologische Bekämpfung von Centaurea maculosa Lam. gefleckte Flockenblume) (Compositae) in Kanada. Mitt. Schweiz. Ent. Ges. 56: 329-342.

1984. Die Strukturanalyse der Wurzelphytophagenkomplexe von Centaurea maculosa Lam. und C. diffusa Lam. (Compositae) in Europa und Interaktionen zwischen wichtigen Phytophagenarten und ihren Wirtspflanzen. Inauguraldissertation, phil. nat. Fakultät, Universität Bern.

1987. Preliminary notes on the use of glass-faced boxes as a tool to study root/herbivore interactions. In Labeyrie, V., G. Fabres, and D. Lachaise (Eds.), Insects-Plants. Dr. W. Junk Publishers, Dordrecht, The Netherlands.

Müller, H., D. Schroeder, and A. Gassmann. 1982. Investigations on Agapeta zoegana L. (Lep. Cochylidae), a possible biocontrol agent of spotted knapweed, Centaurea maculosa Lam. (Compositae) in Canada. Final Report, Commonwealth Institute of Biological Control, Delémont, Switzerland.

Razowski, J. 1970. Cochylidae. In Amsel, H.G., F. Gregor, and H. Reisser (Eds.), Microlepidoptera Palaearctica. Vol. 3. Verlag Georg Fromme \& Co., Wien. 528 pp.

Schroeder, D. 1985. The search for effective biological control agents in Europe:1. Diffuse and spotted knapweed. pp. 103-119 in Delfosse, E.S. (Ed.), Proc. 6th Int. Symp. Biol. Contr. Weeds, Vancouver, B.C., Canada, 1984. Agriculture Canada.

Schütze, K.T. 1931. Die Biologie der Kleinschmetterlinge unter besonderer Berücksichtigung ihrer Nährpflanzen und Erscheinungszeiten. Ent. Ver. Frankfurt a. M. 235 pp.

Southwood, T.R.E. 1978. Ecological Methods-with Particular Reference to the Study of Insect Populations. Chapman and Hall, London and New York, 2nd edition. 524 pp.

Swatchek, B. 1958. Die Larvalsystematik der Wickler (Tortricidae und Carposinidae). Akademie-Verlag, Berlin. pp. 229-230.

Tóth, M., P.M. Guerrin, H.-R. Buser, H. Müller, G. Szöcs, G. Sciraki, and H. Arn. 1985. Z-11-Tetradecenyl acetate: sex attractant of Agapeta zoegana (Lep.: Tortricidae), a potential species for the biological control of knapweed. Can. Ent. 117: 1163-1165.

Wapshere, A.J. 1985. Effectiveness of biological control agents for weeds: present quandaries. Agric. Ecosyst. Environ. 13: 261-280.

Watson, A.K., and A.J. Renney. 1974. The biology of Canadian weeds. 6. Centaurea diffusa and C. maculosa. Can. J. Plant Sci. 54: 687-701.

Walter, H., and H. Lieth. 1964, 1967. Klimadiagramm-Weltatlas, VEB Gustav Fischer Verlag, Jena.

Whaba, W.K. 1970. A method to measure the percentage attack of organisms in the field. pp. 91-93 in Proc. 1st Int. Symp. Biol. Contr. Weeds, Delémont. Misc. Publ. 1, Commonw. Inst. Biol. Control. 